\title{
Ultrasonic-treated fucoidan as a promising therapeutic agent
}

\section{Fukoidan poddany obróbce ultradźwiękowej jako obiecujący środek terapeutyczny}

\author{
Victoria Suprunchuk ${ }^{A-F}$ \\ Department of Pharmaceutical Chemistry and Drug Technology, North-Caucasus Federal University, Stavropol, Russia \\ A - research concept and design; $\mathrm{B}$ - collection and/or assembly of data; $\mathrm{C}$ - data analysis and interpretation; \\ $D$ - writing the article; $E$ - critical revision of the article; $F$ - final approval of the article
}

Polymers in Medicine, ISSN 0370-0747 (print), ISSN 2451-2699 (online)

Polim Med. 2021;51(2):85-90

Address for correspondence

Victoria Suprunchuk

E-mail: vikasuprunchuk@gmail.com

Funding sources

Scholarship of the President of the Russian Federation to young scientists and graduate students ( No. SP-1758.2021.4)

Conflict of interest

None declared

Received on November 3, 2021

Reviewed on November 10, 2021

Accepted on November 15, 2021

Published online on December 15, 2021

Cite as

Suprunchuk V. Ultrasonic-treated fucoidan as a promising therapeutic agent. Polim Med. 2021;51(2):85-90. doi:10.17219/pim/143961

DOI

10.17219/pim/143961

Copyright

C 2021 by Wroclaw Medical University

This is an article distributed under the terms of the

Creative Commons Attribution 3.0 Unported (CC BY 3.0)

(https://creativecommons.org/licenses/by/3.0/)

\begin{abstract}
Fucoidans represent the sulfated heteropolysaccharides that possess a wide range of important pharmacological properties. The properties of a fucoidan depend on several factors, including the molecular weight and the way of extraction. However, the selection of an optimal depolymerization method is necessary to enhance its therapeutic applications. Reducing the molecular weight of fucoidans will make it possible to use them in creating nanoparticles and nanocarriers for, among others, the targeted drug delivery. The molecular mass of the polymer can be changed by means of various methods of depolymerization. In this work, the possibility of application of ultrasonic destruction for decrease in the size of fucoidan molecules for the purpose of expansion of opportunities and spheres of their therapeutic application is considered. This is one of the simple and effective methods of depolymerization of fucoidan, which leads to a decrease in molecular weight without significant structural changes in macromolecules. In addition, methods and potential applications of the ultrasonic extraction of fucoidan from seaweed and the possibilities of their combination are discussed, as well as other physical or chemical methods of extraction.
\end{abstract}

Key words: antioxidant activity, fucoidan, depolymerization, ultrasonic treatment, ultrasonic extraction

\section{Streszczenie}

Fukoidany to siarczanowane heteropolisacharydy o szerokim zakresie farmakologicznie ważnych właściwości. Właściwości fukoidanu zależą od wielu czynników, w tym masy cząsteczkowej i metody ekstrakcji. Jednak w celu poszerzenia możliwości zastosowania terapeutycznego konieczny jest dobór optymalnej metody depolimeryzacji. Zmniejszenie masy cząsteczkowej fukoidanów pozwoli na ich wykorzystanie do tworzenia nanocząstek i nanonośników, w tym do ukierunkowanego dostarczania leków. Masę cząsteczkową polimeru można zmienić przy użyciu różnych metod depolimeryzacji. W niniejszej pracy rozważono możliwość wykorzystania destrukcji ultradźwiękowej do zmniejszenia wielkości cząsteczek fukoidanu. Metoda ta jest jedną z prostych i skutecznych metod depolimeryzacji fukoidanu, która prowadzi do spadku masy cząsteczkowej bez istotnych zmian strukturalnych w makrocząsteczkach. Omówiono również metody i możliwości ekstrakcji ultradźwiękowej fukoidanów z alg, a także możliwośćł łączenia ich z innymi fizycznymi lub chemicznymi metodami ekstrakcji.

Słowa kluczowe: aktywność przeciwutleniająca, ekstrakcja ultradźwiękowa, fucoidan, depolimeryzacja, obróbka ultradźwiękowa 


\section{Introduction}

Fucoidans are of a great interest among biopolymers of marine origin. Fucoidan is a branched sulfated heteropolysaccharide isolated from brown algae and some marine invertebrates. ${ }^{1}$ The main monomeric unit of fucoidan is L-fucose. However, the presence in the structure of some amounts of residues of glucose, mannose, xylose $^{2}$, galactose $\mathrm{e}^{3,4}$ and glucuronic acid was also established. The structure of fucoidans itself is not uniform and the 2 most common types of backbone can be distinguished. The $1^{\text {st }}$ type is the $1 \rightarrow 3$-related residues of $\alpha$-L-fukopyranose, the $2^{\text {nd }}$ type is alternating $1 \rightarrow 3$ - and $1 \rightarrow 4$-related residues of $\alpha$-L-fukopyranose. ${ }^{6}$ In addition to sulfate groups, which are usually located at the $\mathrm{C}-2$, C-3 and/or C-4 carbon atom of the fucose ring, ${ }^{7,8}$ there are acetate groups at the positions $\mathrm{C}-4$ (at the $1 \rightarrow 3$-related fucose residues) and $\mathrm{C}-3$ (at $1 \rightarrow 4$-bonds). ${ }^{8}$ The properties of the polysaccharide depend on the structural characteristics of the polysaccharide determined by a group of factors (the place of growth, the raw material, the time of its collection, the method of extraction, etc.) and require the selection of an optimal method for obtaining its extraction. The molecular weight of such polysaccharides can vary widely. Low-molecular-weight (3-8 kDa), medium- (from $30 \mathrm{kDa}$ ) and high-molecular-weight fucoidans are isolated (may exceed $2000 \mathrm{kDa}$ ). Fucoidan has a wide range of biological activity, including immunomodeling, ${ }^{9}$ antimicrobial, ${ }^{10}$ anti-inflammatory, ${ }^{11}$ anticancer, ${ }^{12}$ and antiviral activity. ${ }^{13}$ It enhances the activity of natural killers, macrophages, dendritic cells and T-cells, ${ }^{14}$ and stimulates hemopoies. ${ }^{15}$ There is an increasing interest in the possibility of its use as an adjuvant. An adjuvant effect is observed when the vaccine is administered orally. ${ }^{16} \mathrm{Immu}$ nomodulation is observed after absorption of the vaccine in the small intestine. The presence of sulfate ester groups confers a negative charge on the skeleton ${ }^{17}$ and in general, the mechanism of action of this polysaccharide in biological interactions with various targets is based on the charge density and chemical properties of the biopolymer itself. ${ }^{17,18}$

The industrial production of fucoidan and functional products with its contents is expanding. ${ }^{19}$ For these purposes, fractions of low-molecular-weight fucoidan are used more often, since some high-molecular-weight fucoidans have a strong branching of the molecule, which leads to an increase in viscosity ${ }^{20}$ and a decrease in the absorption of the polysaccharide due to "limited transport" through the cell membrane". ${ }^{1}$

Furthermore, low-molecular-weight fucoidans exhibit higher biological activity. ${ }^{22}$ In such a way, for the use of fucoidan in the pharmaceutical and food industries, it is necessary to develop a quick and easy way to produce low-molecular-weight fucoidan with specified physicochemical properties. Ultrasonic exposure can lead to faster reactions and processes. For polysaccharides, ultrasound is used to extract them from raw materials or through depolymerization process, ${ }^{23}$ since the generated acoustic energy is sufficient both to destroy the cell wall of the raw materials ${ }^{24}$ and to break bonds in polymer structures. ${ }^{25}$

\section{Ultrasound}

\section{as a depolymerizing factor}

Low-frequency ultrasonic exposure is applicable to the depolymerization of polymeric materials, including naturally occurring ones, and has been used to depolymerize various biopolymers, including polysaccharides, DNA, etc., without altering their chemical structure. ${ }^{26}$

Ultrasonic degradation is characterized by a high decomposition rate of large molecules with a narrow molecular weight distribution, ${ }^{27}$ which allows to obtain an aqueous polymer solution without introducing additional purification steps. To reduce the molecular weight of polymers, ultrasonic waves with a frequency of $16 \mathrm{kHz}$ are used..$^{23}$ Ultrasonic processing is based on the phenomenon of cavitation. As a result of cavitation, shock waves, intense local heating (about $5000^{\circ} \mathrm{C}$ ) and high pressure (about 1000 atm) are created (Fig. 1). ${ }^{28}$ The energy is released to break bonds in any polymeric material, ${ }^{25}$ including glycosidic bonds in polysaccharides. ${ }^{29}$

The primary, secondary, and physical sonochemical effects are isolated. The primary effect is associated with all processes occurring in the gas phase inside the bubble, the secondary effect in the solution phase, and the physical effect is caused by the shockwave. ${ }^{30}$ It is assumed that polymer chain rupture as a result of sonolysis is not random, but is carried out in the middle of the molecule, with a greater effect observed when exposed to low-frequency ultrasound. ${ }^{31}$ Polysaccharides have also been found to depolymerize more rapidly in dilute solutions and with the increased ultrasound time. ${ }^{32}$

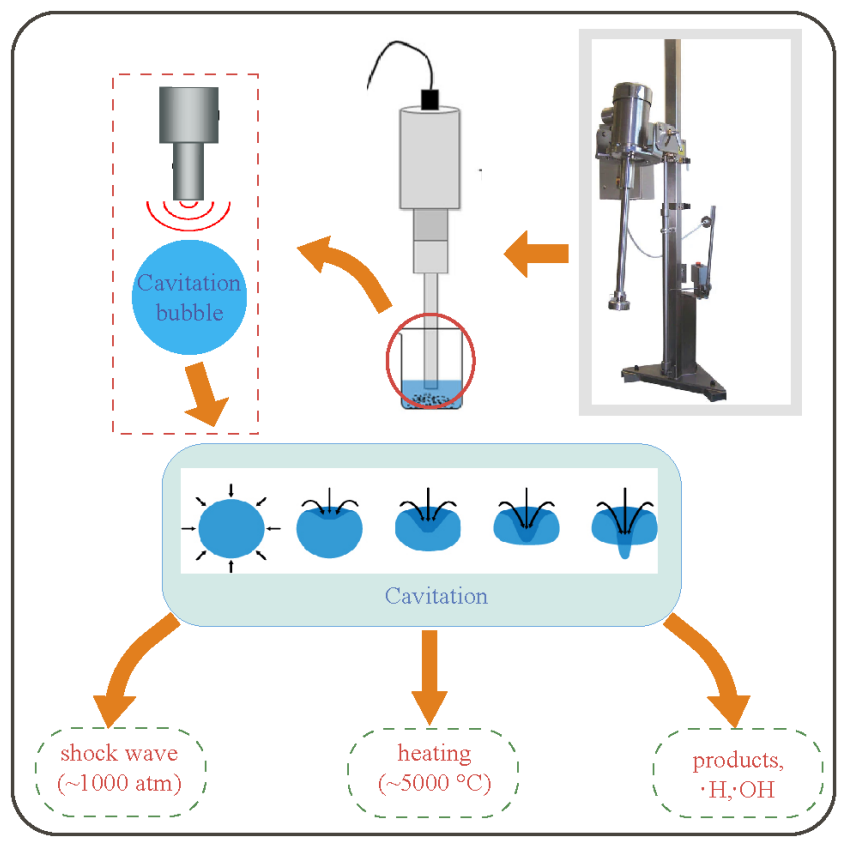

Fig. 1. Types of ultrasonic emission 
In addition, it is known that with prolonged and intense exposure to an ultrasonic field, the energy transfer is dampened and fragments of polysaccharides larger than $20 \mathrm{kDa}$ are formed. ${ }^{33}$ Therefore, to increase the effectiveness of ultrasonic exposure, a combination of other physical methods is possible, such as radical depolymerization, ${ }^{34}$ or introducing additional chemicals into the treatment medium. ${ }^{35}$ The ultrasonic treatment itself is possible in a neutral, acidic and alkaline medium. Upon ultrasonic exposure at $300 \mathrm{~W}$ to a chitosan solution in acetate buffer with $\mathrm{pH} 4.4$ and a concentration of $0.2 \%, 0.8 \%, 1.4 \%$ and $2.0 \%$, the polydispersity decreased from 10.10 to 2.11 , $3.11,4.04$, and 5.09, respectively. ${ }^{36}$ The use of an alkaline medium is possible with low solubility of the depolymerized component or complex, where cleavage occurs from the surface of the swollen particles. ${ }^{37}$

Hydroxyl radicals generated using ultraviolet cavitation also make a great contribution to bond breaking, including glycosidic ones. Therefore, in polysaccharide depolymerization, additional introduction of hydrogen peroxide $\left(\mathrm{H}_{2} \mathrm{O}_{2}\right)$ is possible, which catalyzes radical hydrolysis under the action of ultrasonic waves. ${ }^{38}$ This ultrasonic treatment leads to the formation of products with a low polydispersity index (PI $=1.38 \pm 0.001) .{ }^{38}$ The efficiency of the depolymerization process itself is improved. High molecular weight (MW) exopolysaccharide produced by a deep-sea hydrothermal bacterium Alteromonas macleodii subsp. fijiensis biovar deepsane is halved compared to ultrasonic treatment without hydrogen peroxide (MW $=204.5-112.7 \mathrm{~g} /$ mol). ${ }^{34}$ Metal ions can be used as catalysts to increase the amount of hydroxyl radicals in the system. An example of such ions are Fenton systems where $\mathrm{Fe}^{2+}$ ions act as a catalyst for the production of such radicals. ${ }^{33}$ Ultrasound synergistically increases the effectiveness of the Fenton reaction in decomposing pectin from $448 \mathrm{kDa}$ to $5.5 \mathrm{kDa}$ in just $35 \mathrm{~min},{ }^{33}$ and heparin from $14,8 \mathrm{kDa}$ to $4.87 \mathrm{kDa}$ within $20 \mathrm{~min} .{ }^{39}$ In the process of such depolymerization, no significant chemical changes in the backbone occur, including fucoisylated chondroitin sulfate and loss of sulfate groups. ${ }^{40}$ Moreover, when Fenton depolymerization based on the $\mathrm{H}_{2} \mathrm{O}_{2}$ /ascorbic system acid is used, the increase in efficiency of decomposition of fucosylated chondroitin sulfate without loss of fucoidan branches is observed. ${ }^{41}$

\section{Ultrasonic depolymerization of fucoidans}

The main property determining the functional value of the polymers is the MW distribution. ${ }^{42}$ Unlike acid hydrolysis, ultrasonic depolymerization leads to the production of fucoidan oligomers without changing the monomer composition and quantitative content of sulfo groups. ${ }^{19}$ However, the decrease in MW must be controlled because a decrease below the optimal value for a given activity can lead to the loss of this activity. ${ }^{21}$ Therefore, it is known that the inhibition of $\alpha$-amylase activity is possible by fractions of fucoidan with a molecular weight of $637 \mathrm{kDa}$ and $2351 \mathrm{kDa}$. Fractions with a molecular weight below $43 \mathrm{kDa}$ no longer possess this ability. ${ }^{21,43}$

Ultrasonic degradation has been found to not lead to significant structural changes in fucoidan macromolecules. ${ }^{44}$ When sonochemically treated in an aqueous medium, fucoidan isolated from sea cucumber at an intensity of $508 \mathrm{~W} / \mathrm{cm}^{2}$ and a frequency of $21-25 \mathrm{kHz}$ retained repeated linear tetrasaccharide blocks only with partial destruction of unsulfated fucose units. ${ }^{45}$ After 220 min of such treatment, the average molecular weight of fucoidan decreased from 338 to $91 \mathrm{kDa}$. Depolymerization of fucoidan from Sargassum fulvellum by high-intensity low-frequency treatment $(25 \mathrm{kHz}, 200 \mathrm{~W})$ in the presence of $\mathrm{H}_{2} \mathrm{O}_{2}$ leads to the acceleration of the decomposition of fucoidan. The resulting product retained the structural features of the original biopolymer without altering the functional groups, such as sulfate and monosaccharide units. ${ }^{46}$ The infrared (IR) spectra of the treated fucoidan were identical to the spectrum of the native polysaccharide, with the exception of the peak of the bond stretch absorption band $\mathrm{C}=\mathrm{O}\left(1730 \mathrm{~cm}^{-1}\right)$ and the peak of asymmetric bond stretch $\mathrm{COO}^{-}\left(1630 \mathrm{~cm}^{-1}\right)$.

At an ultrasonic depolymerization of a fucoidan from Sargassum muticum, the shift of peaks of molecular weight from $80 \mathrm{kDa}$ and $40 \mathrm{kDa}$ up to $65 \mathrm{kDa}$ and $25 \mathrm{kDa}$, accompanied with the increase in antioxidant properties of polysaccharide, with the maximum value of indicators of samples processed at $80 \mathrm{kHz}$ within $120 \mathrm{~min}$ is observed. These samples have also shown the inhibiting action on growth of cells of carcinoma of a neck of the womb (HeLa 229). ${ }^{47}$

The further use of depolymerized fucoidan is possible in various fields, including the creation of nanoparticles and nanocarriers. At the same time, the use of high-molecular-weight fucoidan leads to the production of only large particles. For example, when high-molecular-weight fucoidan reacts with chitosan, large aggregates are formed. ${ }^{48}$ With a decrease in the size of fucoidan, the size of particles formed with chitosan also decreases. Thus, with a decrease in molecular weight from $340 \mathrm{kDa}$ to $123 \mathrm{kDa}$ in a ratio of fucoidan to chitosan $1: 1$, there is a drop in the size of the formed particles by $50-70 \mathrm{~nm}$. Furthermore, an increase in the quantitative content of fucoidan in the system at some stages led to an increase in the difference of nanoparticles size. ${ }^{48}$

\section{Ultrasonic extraction of fucoidan}

The main method for extracting fucoidans from raw materials is the use of acid solutions at a temperature of $70-100^{\circ} \mathrm{C}$ with the separation of alginates using $\mathrm{Ca}^{2+}$. ${ }^{29}$ The $\mathrm{H}_{2} \mathrm{O}_{2}$ can be used to remove polyphenolic compounds. However, it is now increasingly popular to use physical 

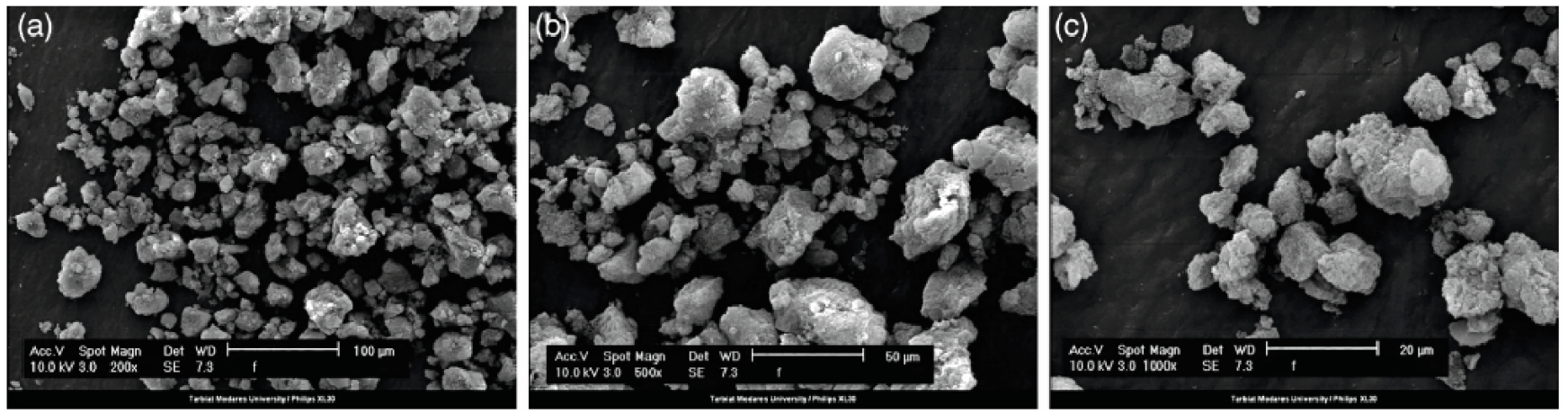

Fig. 2. Scanning electron microscope $\left(\right.$ SEM) picture $(\times 200, \times 500$ and $\times 1000)$ of fucoidan extracted with ultrasonics ${ }^{54}$

extraction methods to reduce or eliminate the complete use of toxic solvents with an increased extraction efficiency. ${ }^{21}$ However, it is necessary to control and optimize the ultrasonic processing time of the raw material to avoid damage to the target compound. ${ }^{50}$

The ultrasonic extraction of fucoidan from the raw material is carried out under the influence of low-frequency ultrasound with a short duration in time, possibly in an acidified medium. In addition, both aqueous and alcoholic systems may be used as the treatment medium. Treatment of Sargassum muticum in water with ultrasound at a frequency of $40 \mathrm{kHz}$, with a power of $150 \mathrm{~W}$ for $5-30 \mathrm{~min}$ at $25^{\circ} \mathrm{C}$ led to the production of fucoidan with a high yield $(147.6 \pm 8.0 \mathrm{~g} / \mathrm{kg}$ of raw materials). ${ }^{51}$ The combination of such extraction with ion exchange chromatography allowed the total fucoidan fraction from the Fucus evanescens brown algae to be divided into 2 fractions at a ratio of 1:0.2. ${ }^{52}$ The fractions differ in structural characteristics, namely the presence and location of the acetate group, the content of galactose and xylose residues. ${ }^{52} \mathrm{With}$ respect to the structural features, fucoidan isolated by ultrasound has a lower fucose content. ${ }^{53}$ The fucoidan obtained by ultrasonic extraction from Nizamuddinia zanardinii spp. at a ratio of water to raw materials of 80:1 (power $196 \mathrm{~W}$, extraction temperature $70^{\circ} \mathrm{C}$ for $58 \mathrm{~min}$ ) showed a noticeable inhibition of the growth of cancer cells HeLa (62.36\%) and HepG2 (56.83\%) (Fig. 2). ${ }^{54}$

In the work of Okolie et al., the extraction was carried out by ultrasound at a frequency of $20 \mathrm{kHz}$ for $35 \mathrm{~min}$ in an aqueous medium containing $0.01 \mathrm{M} \mathrm{HCl}$, followed by the treatment of the extract with $2 \%(\mathrm{w} / \mathrm{v}) \mathrm{CaCl}_{2}$ and 4 volumes of $95 \%$ ethanol. ${ }^{55}$ The fucoidan obtained from Ascophyllum nodosum spp. showed a high prebiotic activity similar to that of the standard prebiotic inulin. The addition of fucoidan extracts to MRS (de Man, Rogosa and Sharpe) broth, with a final concentration of 0.1 and $0.5 \%$, significantly $(\mathrm{p}<0.05)$, but not dose-dependently, improved the growth of Lactobacillus delbrueckii subsp. bulgaricus strain. ${ }^{55} \mathrm{When}$ alcohol was used as a solvent in ultrasonic extraction, the fucoidan yield increased by $16.8 \%$, compared to the extraction with hot water. In this way, fucoidan was obtained from Sargassum mcclurei at a solvent to algae ratio of $24: 1$, the extraction time of $49 \mathrm{~min}$ at $54^{\circ} \mathrm{C}$, with the ultrasound power being $360 \mathrm{~W} .{ }^{56}$
Ultrasonic exposure is also known to lead to an increase in enzyme activity when used together. The enzymatic ultrasonic extraction method allows for obtaining a lower molecular weight polysaccharide with a higher fucoidan yield compared to the ultrasonic method (from $3.6 \%$ to $7.87 \%) .{ }^{57}$ The average molecular weight of fucoidan isolated by the ultrasonic method was $1020.85 \mathrm{kDa}$ and enzymatic ultrasonic was $443.70 \mathrm{kDa} .{ }^{57}$

In addition to chemical agents, ultrasonic exposure during extraction can be combined with other mechanical effects. For example, the combination of ultrasonic exposure $\left(200 \mathrm{~W}, 20 \mathrm{kHz}, 55^{\circ} \mathrm{C}\right)$ and microwave exposure $(700 \mathrm{~W}$, $90^{\circ} \mathrm{C}$ ) resulted in an increase in the fucoidan sulfate content of $27.16 \% .{ }^{58}$

\section{Conclusions}

Due to the biological activity of fucoidans, interest in them remains high. However, the selection of an optimal depolymerization method is necessary to enhance their therapeutic applications. Reducing the molecular weight of fucoidans will make it possible to use them in creating nanoparticles and nanocarriers for, among others, the targeted drug delivery. Ultrasound destruction is applicable for these purposes. This is one of the simple and effective methods of fucoidan depolymerization, which leads to the decrease in molecular weight without significant structural changes in macromolecules. This approach is simple and can be used on an industrial scale. The ultrasonic extraction method is useful for extracting fucoidans from algae. Yet, the use of the ultrasonic method in combination with chemical (for example, acidic, enzymatic) and physical (for example, microwave radiation) methods allows to increase the yield of the desired product.

\section{ORCID iDs}

Victoria Suprunchuk (1) https://orcid.org/0000-0002-5587-8262

\section{References}

1. Wang $Y$, Xing $M, C a o ~ Q$, Aiguo J, Liang $H$, Song S. Biological activities of fucoidan and the factors mediating its therapeutic effects: A review of recent studies. Mar Drugs. 2019;17(3):183. doi:10.3390/ md17030183 
2. Cong Q, Chen H, Liao W, et al. Structural characterization and effect on anti-angiogenic activity of a fucoidan from Sargassum fusiforme. Carbohydr Polym. 2016;136;899-907. doi:10.1016/j.carbpol.2015.09.087

3. Cuong HD, Thuy TTT, Huong TT, Ly BM, Van TTT. Structure and hypolipidaemic activity of fucoidan extracted from brown seaweed Sargassum henslowianum. Nat Prod Res. 2015;29(5):411-415. doi:10.1080 /14786419.2014.948436

4. Bilan MI, Grachev AA, Shashkov AS, Nifantiev NE, Usov AI. Structure of a fucoidan from the brown seaweed Fucus serratus L. Carbohydr Res. 2006;341(2):238-245. doi:10.1016/j.carres.2005.11.009

5. Ale MT, Maruyama H, Tamauchi H, Mikkelsen JD, Meyer AS. Fucoidan from Sargassum sp. and Fucus vesiculosus reduces cell viability of lung carcinoma and melanoma cells in vitro and activates natural killer cells in mice in vivo. Int J Biol Macromol. 2011;49(3):331-336. doi:10.1016/j.ijbiomac.2011.05.009

6. Khatuntseva EA, Ustuzhanina NE, Zatonskii GV, et al. Synthesis, NMR and conformational studies of fucoidan fragments 1:1 desulfated 2,3- and 3,4-branched trisaccharide fragments and constituting disaccharides. J Carbohydr Chem. 2000;19(9):1151-1173. doi:10.1080/ 07328300008544140

7. Yao Y, Yim EKF. Fucoidan for cardiovascular application and the fac tors mediating its activities. Carbohydr Polym. 2021;270:118347. doi:10. 1016/j.carbpol.2021.118347

8. Li B, Lu F, Wei X, Zhao R. Fucoidan: Structure and bioactivity. Molecules. 2008;13(8):1671-1695. doi:10.3390/molecules13081671

9. Yoo HJ, You D, Lee K. Characterization and immunomodulatory effects of high molecular weight fucoidan fraction from the sporophyll of Undaria pinnatifida in immunosuppressed mice. Mar Drugs. 2019;17(8):447. doi:10.3390/md17080447

10. Zhao X, Guo F, Hu J, et al. Antithrombotic activity of oral administered low molecular weight fucoidan from Laminaria japonica. Thromb Res. 2016;144:46-52. doi:10.1016/j.thromres.2016.03.008

11. Hwang PA, Hung YL, Chien SY. Inhibitory activity of Sargassum hemiphyllum sulfated polysaccharide in arachidonic acid-induced animal models of inflammation. J Food Drug Anal. 2015;23(1):49-56. doi:10. 1016/j.jfda.2014.05.004

12. Jin JO, Chauhan PS, Arukha AP, Chavda V, Dubey A, Yadav D. The therapeutic potential of the anticancer activity of fucoidan: Current advances and hurdles. Mar Drugs. 2021;19(5):265. doi:10.3390/md19050265

13. Wang W, Wu J, Zhang X, et al. Inhibition of influenza A virus infection by fucoidan targeting viral neuraminidase and cellular EGFR pathway. Sci Rep. 2017;7:40760. doi:10.1038/srep40760

14. Etman SM, Elnaggar YSR, Abdallah OY. Fucoidan, a natural biopolymer in cancer combating: From edible algae to nanocarrier tailoring Int JBiolMacromol. 2020;147:799-808. doi:10.1016/j.ijbiomac.2019.11.191

15. Li C, Niu Q, Li S, et al. Fucoidan from sea cucumber Holothuria polii: Structural elucidation and stimulation of hematopoietic activity. Int J Biol Macromol. 2020;154:1123-1131. doi:10.1016/j.ijbiomac.2019. 11.036

16. Dorrington MG, Bowdish DME. Immunosenescence and novel vaccination strategies for the elderly. Front Immunol. 2013;4:171. doi:10. 3389/fimmu.2013.00171

17. Zayed A, El-Aasr M, Ibrahim AS, Ulber R. Fucoidan characterization: Determination of purity and physicochemical and chemical properties. Mar Drugs. 2020;18(11):571. doi:10.3390/md18110571

18. Bilan MI, Usov AI. Structural analysis of fucoidans. Nat Prod Commun 2008;3(10):1639-1648. doi:10.1177/1934578X0800301011

19. Fernando IPS, Kim D, Nah JW, Jeon YJ. Advances in functionalizing fucoidans and alginates (bio)polymers by structural modifications: A review. Chem Eng J. 2019;355:33-48. doi:10.1016/j.cej.2018.08.115

20. Rioux LE, Turgeon SL, Beaulieu M. Characterization of polysaccharides extracted from brown seaweeds. Carbohydr Polym. 2007;69(3): 530-537. doi:10.1016/j.carbpol.2007.01.009

21. Flórez-Fernández N, Torres MD, González-Muñoz MJ, Domínguez H Potential of intensification techniques for the extraction and depolymerization of fucoidan. Algal Res. 2018;30:128-148. doi:10.1016/j. algal.2018.01.002

22. Morya VK, Kim J, Kim EK. Algal fucoidan: Structural and size-dependent bioactivities and their perspectives. Appl Microbiol Biotechnol. 2012;93(1):71-82. doi:10.1007/s00253-011-3666-8

23. Cui R, Zhu F. Ultrasound modified polysaccharides: A review of structure, physicochemical properties, biological activities and food applications. Trends Food Sci Technol. 2021;107:491-508. doi:10.1016/j.tifs.2020.11.018
24. Chemat F, Rombaut N, Sicaire A, Meullemiestre A, Abert-Vian M. Ultrasonics sonochemistry ultrasound assisted extraction of food and natural products: Mechanisms, techniques, combinations, protocols and applications. A review. Ultrason Sonochem. 2017;34:540-560. doi:10.1016/j.ultsonch.2016.06.035

25. Mason TJ, Newman AP, Phull S. Sonochemistry in water treatment. In: White MJD, ed. 2nd International Conference on Advances in Water and Effluent Treatment. London, UK: Professional Engineering Publishing; 1993:243-250.

26. Szu S, Zon G, Schneerson R, Robbins J. Ultrasonic irradiation of bacterial polysaccharides: Characterization of the depolymerized products and some applications of the process. Carbohydr Res. 1986; 152:7-20. doi:10.1016/s0008-6215(00)90283-0

27. Yan JK, Wang YY, Ma HL, Wang ZB. Ultrasonic effects on the degradation kinetics, preliminary characterization and antioxidant activities of polysaccharides from Phellinus linteus mycelia. Ultrason Sonochem. 2016;29:251-257. doi:10.1016/j.ultsonch.2015.10.005

28. Suslik KS, Fang M, Hyeon T, Mdleleni M. Applications of sonochemestry to materials synthesis. In: Crum LA, Mason TJ, Reisse JL, Suslick KS, eds. Sonochemistry and Sonoluminescence. Dordrecht, the Netherlands: Springer; 1999:291-320.

29. Ribeiro AR, Nunes OC, Pereira MFR, Silva AMT. An overview on the advanced oxidation processes applied for the treatment of water pollutants defined in the recently launched Directive 2013/39/EU. Environ Int. 2015;75:33-51. doi:10.1016/j.envint.2014.10.027

30. Xu H, Zeiger BW, Suslick KS. Sonochemical synthesis of nanomaterials. Chem Soc Rev. 2013;42(7):2555-2567. doi:10.1039/c2cs35282f

31. Portenlänger $G$, Heusinger $H$. The influence of frequency on the mechanical and radical effects for the ultrasonic degradation of dextranes. Ultrason Sonochem. 1997;4(2):127-130. doi:10.1016/s13504177(97)00018-7

32. Liu H, Bao J, Du Y, Zhou X, Kennedy JF. Effect of ultrasonic treatment on the biochemphysical properties of chitosan. Carbohydr Polym. 2006;64(4):553-559. doi:10.1016/j.carbpol.2005.11.007

33. Zhi Z, Chen J, Li S, et al. Fast preparation of RG-I enriched ultra-low molecular weight pectin by an ultrasound accelerated Fenton process. Sci Rep. 2017;7(1):541. doi:10.1038/s41598-017-00572-3

34. Petit A, Noiret N, Guezennec J, Gondexon N, Colliec-Jouault S. Ultrasonic depolymerization of an exopolysaccharide produced by a bacterium isolated from a deep-sea hydrothermal vent polychaete annelid. Ultrason Sonochem. 2007;14(2):107-112. doi:10.1016/j.ultsonch.2006. 03.010

35. Baytas SN, Linhardt RJ. Advances in the preparation and synthesis of heparin and related products. Drug Discov Today. 2020;25(12): 2095-2109. doi:10.1016/j.drudis.2020.09.011

36. Chen RH, Chang JR, Shyur JS. Effects of ultrasonic conditions and storage in acidic solutions on changes in molecular weight and polydispersity of treated chitosan. Carbohydr Res. 1997;299(4):287-294. doi:10.1016/S0008-6215(97)00019-0

37. Mislovicová D, Masárová J, Bendzálová K, Soltés L, Machová E. Sonication of chitin-glucan, preparation of water-soluble fractions and characterization by HPLC. Ultrason Sonochem. 2000;7(2):63-68. doi:10.1016/s1350-4177(99)00030-9

38. Achour O, Bridiau N, Godhbani A, et al. Ultrasonic-assisted preparation of a low molecular weight heparin (LMWH) with anticoagulant activity. Carbohydr Polym. 2013;97(2):684-689. doi:10.1016/j.carbpol.2013.05.046

39. Zhi Z, Li J, Chen J, et al. Preparation of low molecular weight heparin using an ultrasound-assisted Fenton system. Ultrason Sonochem. 2019;52:184-192. doi:10.1016/j.ultsonch.2018.11.016

40. Li J, Li S, Zhi Z, et al. Depolymerization of fucosylated chondroitin sulfate with a modified Fenton system and anticoagulant activity of the resulting fragments. Mar Drugs. 2016;14(9):170. doi:10.3390/ md14090170

41. Li J, Li S, Wu L, et al. Ultrasound-assisted fast preparation of low molecular weight fucosylated chondroitin sulfate with antitumor activity. Carbohydr Polym. 2019;209:82-91. doi:10.1016/j.carbpol.2018.12.061

42. Nair LS, Laurencin CT. Biodegradable polymers as biomaterials. Prog Polym Sci. 2007;32(8-9):762-798. doi:10.1016/j.progpolymsci. 2007.05.017

43. Kim KT, Rioux LE, Turgeon SL. Molecular weight and sulfate content modulate the inhibition of a-amylase by fucoidan relevant for type 2 diabetes management. PharmaNutrition. 2015;3(3):108-114. doi:10.1016/j.phanu.2015.02.001 
44. Zhu B, Ni F, Xiong Q, Yao Z. Marine oligosaccharides originated from seaweeds: Source, preparation, structure, physiological activity and applications. Crit Rev Food Sci Nutr. 2020;61(1):60-74. doi:10.1080/1040 8398.2020.1716207

45. Guo X, Ye X, Sun Y, et al. Ultrasound effects on the degradation kinetics, structure, and antioxidant activity of sea cucumber fucoidan. J Agric Food Chem. 2014;62(5):1088-1095. doi:10.1021/jf404717y

46. Jo BW, Choi S. Degradation of fucoidans from Sargassum fulvellum and their biological activities. Carbohydr Polym. 2014;111:822-829. doi:10.1016/j.carbpol.2014.05.049

47. Torres MD, Flórez-Fernández N, Domínguez H. Monitoring of the ultrasound assisted depolymerisation kinetics of fucoidans from Sargassum muticum depending on the rheology of the corresponding gels. J Food Eng. 2021;294:110404. doi:10.1016/j.jfoodeng.2020.110404

48. Rasin AB, Shevchenko NM, Silchenko AS, et al. Relationship between the structure of a highly regular fucoidan from Fucus evanescens and its ability to form nanoparticles. Int J Biol Macromol. 2021;185: 679-687. doi:10.1016/j.ijbiomac.2021.06.180

49. Ale MT, Mikkelsen JD, Meyer AS. Important determinants for fucoidan bioactivity: A critical review of structure-function relations and extraction methods for fucose-containing sulfated polysaccharides from brown seaweeds. Mar Drugs. 2011;9(10):2106-2130. doi:10.3390/ md9102106

50. Shirsath SR, Sonawane SH, Gogate PR. Intensification of extraction of natural products using ultrasonic irradiations: A review of current status. Chem Eng Process Process Intensif. 2012;53:10-23. doi:10.1016/j. cep.2012.01.003

51. Flórez-Fernández N, López-García M, González-Muñoz MJ, López Vilariño JM, Domínguez H. Ultrasound-assisted extraction of fucoidan from Sargassum muticum. J Appl Phycol. 2017;29:1553-1561. doi:10.1007/s10811-016-1043-9
52. Hmelkov AB, Zvyagintseva TN, Shevchenko NM, Rasin AB, Ermakova SP. Ultrasound-assisted extraction of polysaccharides from brown alga Fucus evanescens: Structure and biological activity of the new fucoidan fractions. J App/ Phycol. 2018;30(3):2039-2046. doi:10.1007/ s10811-017-1342-9

53. Hanjabam MD, Kumar A, Tejpal CS, Krishnamoorthy E, Kishore P, Kumar KA. Isolation of crude fucoidan from Sargassum wightii using conventional and ultra-sonication extraction methods. Bioact Carbohydrates Diet Fibre. 2019;20:100200. doi:10.1016/j.bcdf.2019.100200

54. Alboofetileh M, Rezaei M, Tabarsa M, You S. Ultrasound-assisted extraction of sulfated polysaccharide from Nizamuddinia zanardinii: Process optimization, structural characterization, and biological properties. J Food Process Eng. 2019;42(2):1-13. doi:10.1111/jfpe.12979

55. Okolie LC, Mason B, Mohan A, Pitts N, Udenigwe C. The comparative influence of novel extraction technologies on in vitro prebioticinducing chemical properties of fucoidan extracts from Ascophyllum nodosum. Food Hydrocoll. 2019;90:462-471. doi:10.1016/j.foodhyd. 2018.12.053

56. My PLT, Sung VV, Dat TD, Nam HM, Phong MT, Hieu NH. Ultrasound-assisted extraction of fucoidan from Vietnamese brown seaweed Sargassum mcclurei and testing bioactivities of the extract. ChemistrySelect. 2020;5(14):4371-4380. doi:10.1002/slct.201903818

57. Alboofetileh M, Rezaei M, Tabarsa M, You SG. Bioactivities of Nizamuddinia zanardinii sulfated polysaccharides extracted by enzyme, ultrasound and enzyme-ultrasound methods. J Food Sci Technol. 2019;56(3):1212-1220. doi:10.1007/s13197-019-03584-1

58. Alboofetileh $M$, Rezaei $M$, Tabarsa $M$, et al. Effect of different nonconventional extraction methods on the antibacterial and antiviral activity of fucoidans extracted from Nizamuddinia zanardinii. Int J BiolMacromol. 2019;124:131-137. doi:10.1016/j.jbiomac.2018.11.201 